The journal has had 40 points in Ministry of Education and Science of Poland parametric evaluation. Annex to the announcement of the Minister of Education and Science of December 21, 2021. No. 32343. Has a Journal's Unique Identifier: 201159. Scientific disciplines assigned: Physical Culture Sciences (Field of Medical sciences and health sciences); Health Sciences (Field of Medical Sciences and Health Sciences).

Punkty Ministerialne z 2019 - aktualny rok 40 punktów. Zalącznik do komunikatu Ministra Edukacji i Nauki z dnia 21 grudnia 2021 r. Lp. 32343. Posiada Unikatowy Identyfikator Czasopisma: 201159. Przypisane dyscypliny naukowe:Nauki o kulturze fizycznej (Dziedzina nauk medycznych i nauk o zdrowiu); Nauki o zdrowiu (Dziedzina nauk medycznych i nauk o zdrowiu).

(c) The Authors 2022;

This article is published with open access at Licensee Open Journal Systems of Nicolaus Copernicus University in Torun, Poland

Open Access. This article is distributed under the terms of the Creative Commons Attribution Noncommercial License which permits any noncommercial use, distribution, and reproduction in any medium, provided the original author (s) and source are credited. This is an open access article licensed under the terms of the Creative Commons Attribution Non commercial license Share alike.

(http://creativecommons.org/licenses/by-nc-sa/4.0/) which permits unrestricted, non commercial use, distribution and reproduction in any medium, provided the work is properly cited. The

Received: 26.01.2022. Revised: 26.01.2022. Accepted: 05.02.2022.

\title{
Complex Regional Pain Syndrome - Prevention, diagnosis and treatment
}

Aleksandra Mazurek aleksandramazurek7@gmail.com Poznań University of Medical Sciences ul. A. Fredry 11, 61-701 Poznań, Poland

Katarzyna Cyboran katarzyna_cyboran@o2.pl Medical Faculty, Institute of Medical Sciences, Collegium Medicum, Oleska Street 48, 45-052 Opole Poland

Monika Kuc kuc.monika96@gmail.com ; Medical Faculty, Institute of Medical Sciences, Collegium Medicum, Oleska Street 48, 45-052 Opole Poland

Dominik Machaj Faculty of Medicine Medical University of Lublin Chodźki Street 19 20-093 Lublin Poland

Damian Machaj Faculty of Medicine, Medical University of Wroclaw, Wybrzeże L. Pasteura Street 1, 50-367 Wrocław Poland

\section{ABSTRACT}

CRPSdifferentfrom other chronic pain conditions by the presence of signs indicating autonomic and inflammatory changes in the area of pain.[4]Otherwise called Sudeck syndrome, it is characterized by pain and swelling of the affected limb, and in the final stage - contractures in the joints. The skin becomes dry and trophically changed. If the cause of the symptoms is known, causal treatment is used, if not - the following attempts are made to treat this syndrome.The pathophysiology of CRPS is unknown, so diagnostic tests are used to rule out a pathology other thanComplex Regional PainSyndrome.The 
average age of onset is 42 years. Statistically, women suffer from the disease three times more often than men. [7]

KEY WORDS: CRPS, Complex Regional PainSyndrome, Sudeck Syndrome

\section{INTRODUCTION AND PURPOSE}

Complex Regional PainSyndrome(CRPS)revealed strongm, searingmacheem discoloredamiskinymiInpurple in color,sweating swelling of the soft tissues.Pain hypersensitivity is characteristic, usually painless stimuli such as touch or cold are perceived as painful. S.barkbecomesdry anddiluted, trophically altered. It followsrestriction of mobility in the joint,builds upmuscular dystrophyandis progressingbone decalcification.ABOUTfunthe so-calledSudecka Team (CRPS)there aresignificantly bigger,disproportionate to the injury. Mainand causeComplex Regional Pain symptomsSyndromeisInjury-related release of cytokinescentral or peripheral allergy,excessive neurogenic inflammation, sympathetic pain and cortical reorganization in response to chronic painoxidative stress, genetic or psychological factors.[1][4]

Statistically, this syndrome most often affects the ankle joint, hand and wrist, especially after fractures, contusions or sprains of the joint. It most often affects people aged 30-50. CRPS affects four times more women than men. It is especially common in peoplewith a fracture of the radius. It occurs in approximately $7 \%$ of patients after limb fractures, surgery to the limbs, or other injuries.[4]

\section{DESCRIPTION OF THE STATE OF KNOWLEDGE.}

DThe diagnosis of CRPS is symptom-based, as the pathophysiology of this syndrome is not yet fully understood. However, diagnostic tests may be necessary to rule out another disease.

This team was defined byR. Norman Hardenby the following clinical criteria:

1. Continuing pain, which is disproportionate to any inciting event

2. Must report at least one symptom in three of the four following categories:

a) Sensory: Reports of hyperesthesia and / or allodynia

b) Vasomotor: Reports of temperature asymmetry and / or skin color changes and / or skin color asymmetry 
c) Sudomotor / Edema: Reports of edema and / or sweating changes and / or sweating asymmetry

d) Motor / Trophic: Reports of decreased range of motion and / or motor dysfunction (weakness, tremor, dystonia) and / or trophic changes (hair, nail, skin)

3. Must display at least one sign at time of evaluation in two or more of thefollowing categories:

and)Sensory: Evidence of hyperalgesia (to pinprick) and / or allodynia (this light touch and / or temperature sensation and / or deep somatic pressure and / or joint movement)

b)Vasomotor: Evidence of temperature asymmetry $\left(>1^{\circ} \mathrm{C}\right)$ and / or skin color changes and / or asymmetry

c)Sudomotor / Edema: Evidence of edema and / or sweating changes and / or sweating asymmetry

d)Motor / Trophic: Evidence of decreased range of motion and / or motor dysfunction (weakness, tremor, dystonia) and / or trophic changes (hair, nail, skin)

4. There is no other diagnosis that better explains the signs and symptoms[2] ABOUTCurrently, Sudeck Syndrome is divided into type I and type II based on the absence or presence of clinical symptoms of serious damage to peripheral nerves, e.g. abnormalities in theelectromyograpy (EMG). [4]

PreventionCRPSatorthopedic patientsit consists mainly in the quick immobilization of the limbafter an injury in a plaster cast with an appropriate pressure level, sufficiently fast mobilization arthritis, effective pain treatment,quick diagnostics of the beginning symptoms of the Sudeten syndrome.It has been demonstratedthat acceptingvitamin C.in dose 0.5 gper day reduces the risk of occurrencethisteamin case of wrist fracturesa. [3]For prophylaxis, you can also use topical dimethylsulfoxide, orally $\mathrm{N}$-acetylcysteine

Treating CRPS is primarily about treating pain and other symptoms such as swelling. Physiotherapy and occupational therapy (including graded motor imagery - GMI and mirror therapy), bisphosphonates, calcitonin, intravenous ketamine administered, antiepileptic drugs, can also be effective.antidepressants,e.g. duloxetine, free radicals neutralizers,volransdermal lidocaine patchesapplied to the affected areain the initial phase of treatment,oral corticosteroidsopioid painkillers.S.thymulation of the spinal cordit was 
successful in two-thirds of the patients. Other sources say that therapies should be the foundationfunctional, and they describe ketamine as an experimental therapy. [6]In the acute phase of CRPS, doses of 30-40 $\mathrm{mg}$ of prednisone administered orally for two weeks are effective.[4] Ganglion blockade has not been shown to be of significant effectiveness. There is no evidence that psychological interventions are effective, but the inclusion of CBT is considered beneficial as part of chronic patient care.

\section{CONCLUSIONS}

The clinical criteria have been constructed to provide a standardized methodology for the diagnosis of Sudeck Syndrome. Treatment should depend on the cause of the symptoms. However, due to the fact that there is no causal treatment therapy in which corticosteroidoh, antidepressants, bowahexpandingychdishes, transdermal patches with lidocaine, painkillers, nonsteroidal anti-inflammatory drugs, opioids, ganglion blockades, stimulation of the spinal cord, cryotherapy and kinesitherapy and psychotherapy is beeing used. Misdiagnsis and treatment that comes with it can lead to excessive costs and may delay getting the appropriate treatment.[2] Factors that increase the risk of the Sudeten syndrome include:surgical procedures, tightly applied plaster castand,long immobilization, repeated injuries, ischemic diseaseand,hormonal disorders, smoking,depression.

\section{REFERENCES}

1. Birklein, F. (2005). Complex regional pain syndrome.Journal of neurology,252(2), 131-138.

2. Harden, RN, Bruehl, S., Stanton-Hicks, M., \& Wilson, PR (2007). Proposed new diagnostic criteria for complex regional pain syndrome.Pain medicine,8(4), 326-331.

3. Zollinger, PE, Kreis, RW, van der Meulen, HG, van der Elst, M., Breederveld, RS, \& Tuinebreijer, WE (2010). No higher risk of CRPS after external fixation of distal radial fractures - subgroup analysis under randomized vitamin $\mathrm{C}$ prophylaxis.The open orthopedics journal,4, 71 .

4. Bruehl, S. (2015). Complex regional pain syndrome.Bmj,351.

5. Perez, RS, Zollinger, PE, Dijkstra, PU, Thomassen-Hilgersom, IL, Zuurmond, WW,

Rosenbrand, KC, \& Geertzen, JH (2010). Evidence based guidelines for complex regional

pain syndrome type 1.BMC neurology,10(1), 1-14. 
6. Stanton-Hicks, MD, Burton, AW, Bruehl, SP, Carr, DB, Harden, RN, Hassenbusch, SJ, ... \& Rezai, AR (2002). An updated interdisciplinary clinical pathway for CRPS: report of an expert panel.Pain practice,2(1), 1-16.

7. Veldman, PH, Reynen, HM, Arntz, IE, \& Goris, RJA (1993). Signs and symptoms of reflex sympathetic dystrophy: prospective study of 829 patients.The Lancet,342(8878), 1012-1016. 